\title{
Use of speaking valve on preventing respiratory infections, in critical traqueostomized patients diagnosed of dysphagia secondary to artificial airway. edisval study
}

\author{
A Fernández Carmona ${ }^{1 *}$, M Arias Díaz², E Aguilar Alonso ${ }^{3}$, I Macías Guarasa ${ }^{4}$, P Martínez López \\ MA Díaz Castellanos², EDISVAL Group
}

From ESICM LIVES 2015

Berlin, Germany. 3-7 October 2015

\section{Introduction}

Available data shows that dysphagia rate, secondary to artificial airway and prolonged mechanical ventilation, in critical tracheostomized patients is high (50-83\%). Dysphagia is directly related to bronchial aspirations and respiratory infections. The rate of respiratory infections on tracheostomized patients is also very high (Some series next 100\%). The re-establishment of airway using speaking valves allow the rehabilitation and post-recovery of those disorders, as well as deglutition and phonatory system rehabilitation.

\section{Objectives}

Determine the usefulness of speaking valve in preventing respiratory nosocomial infections in critical tracheostomized patients diagnosed of dysphagia secondary to artificial ariway.

\section{Methods}

Pilot phase of randomized multicenter controlled clinical trial. From September 2014 until December 2014, the use of speaking valve was randomized during mechanical ventilation weaning-decannulation phase in critical patients over 18 years, tracheostomized at ICU, diagnosed of dysphagia secondary to artificial airway. This study was carried out of simultaneous form in 7 units of intensive care including centers of the first, second and third level.

Virgen de las Nieves Hospital, Granada, Spain

Full list of author information is available at the end of the article

\section{Results}

27 patients were included, 8 of which were excluded of the record and later analysis because of problems of protocols fulfillment. 19 included patients presented an average of 60,46 years of age, and initial APACHEII 19,07. The average time of mechanical ventilation was 23,6 days. After ramdomisation 11 patients were treated with speaking valve (SVgroup), and 8 by identical protocol without speaking valve (decannulation protocol DPgroup). The incident of infections in the SVgroup was $18,18 \%(2 / 11)$ and $37,5 \%(3 / 8)$ in the DPgroup. Infections in the SVgroup were registered like tracheobronquitis while in DPgroup as pneumonia. It is important to indicate that all the patients included in this study remained under absolute diet. Decannulation time average was 4,4 days in the SVgroup and 6 days in the DPgroup PD. Patients were decannulated when they fulfilled strict criteria (in both groups) including disphagia normalization. The mortality was 0 in the SVgroup and 3 in DPgroup.

There have not been registered side effects of the speaking valve use. After detecting mistakes we have proposed measures to avoid problems of follow-up of protocols. The incorporation of the SV in the different implied units has been easy and very well received.

\section{Conclusions}

Incident of respiratory infectious complications and mortality was minor in the SVgroup. In the following months it will continue the experimental phase of EDISVAL study in order to know if these differences are attributable to speaking valve use.

\section{SpringerOpen ${ }^{\circ}$}

(C) 2015 Fernández Carmona et al.; This is an Open Access article distributed under the terms of the Creative Commons Attribution License (http://creativecommons.org/licenses/by/4.0), which permits unrestricted use, distribution, and reproduction in any medium, provided the original work is properly cited. 


\section{Authors' details}

${ }^{1}$ Virgen de las Nieves Hospital, Granada, Spain. ${ }^{2}$ Hospital Santa Ana, Intensive Care Unit, Motril, Spain. ${ }^{3}$ Hospital Infanta Margarita, Intensive Care Unit, Cabra, Spain. ${ }^{4}$ Hospital Carlos Haya, Intensive Care Unit, Malaga, Spain.

${ }^{5}$ Hospital Virgen de la Victoria, Intensive Care Unit, Malaga, Spain.

Published: 1 October 2015

\section{References}

1. Romero CM: Swallowing dysfunction in nonneurologic critically ill patients who require percutaneous dilatational techeostomy. Chest 2010, 137.

2. Fernández A: Exploration and approach to artificial airway dysphagia. Med Intensiva 2012, 36.

doi:10.1186/2197-425X-3-S1-A936

Cite this article as: Fernández Carmona et al:: Use of speaking valve on preventing respiratory infections, in critical traqueostomized patients diagnosed of dysphagia secondary to artificial airway. edisval study. Intensive Care Medicine Experimental 2015 3(Suppl 1):A936.

\section{Submit your manuscript to a SpringerOpen ${ }^{\mathcal{O}}$ journal and benefit from:}

- Convenient online submission

- Rigorous peer review

- Immediate publication on acceptance

- Open access: articles freely available online

- High visibility within the field

- Retaining the copyright to your article

Submit your next manuscript at $\gg$ springeropen.com 